\title{
EDITORIAL
}

\section{Compuestos bioactivos de la macro región árida de los Andes. ¿Potencial económico infravalorado?}

\author{
Bioactive compounds from the arid macro-region of the Andes. \\ An undervalued economic potential?
}

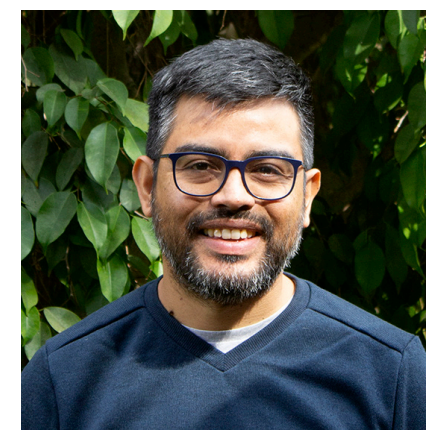

Claudio Parra Montes

Facultad de Ciencias Agronómicas

Universidad de Tarapacá,

Arica, Chile.

cparra@uta.cl

En los últimos años han aparecido una serie de enfermedades cada vez más frecuentes denominadas enfermedades no transmisibles, las cuales no se propagan de persona a persona, tienen una larga duración y suelen evolucionar lentamente. Las enfermedades cardiovasculares, las enfermedades respiratorias crónicas, la diabetes y el cáncer son algunas de las afecciones de este tipo más prevalentes. Con respecto al cáncer, la Organización Mundial de la Salud (OMS) informó que 8,8 millones de muertes se deben a esta causa, es decir, una de cada seis muertes en el mundo. Por otro lado, los agentes quimioterapéuticos utilizados tradicionalmente para el tratamiento del cáncer tienen alta toxicidad, multirresistencia y falta de selectividad, lo que limita su efectividad. Por tanto, la búsqueda y el desarrollo de nuevos compuestos activos juegan un papel importante en el control del cáncer.

En este contexto, la macro región árida de los Andes presenta características únicas para la búsqueda de nuevos compuestos bioactivos. Esta zona se extiende desde el centro-sur de Perú hasta el norte de Argentina y Chile con una altitud que varía de 2.500 a $5.000 \mathrm{msnm}$. Igualmente, esta
In recent years, a series of increasingly frequent diseases called non-communicable diseases have appeared, which are not transferred from person to person, have a long duration, and tend to evolve slowly. Cardiovascular diseases, chronic respiratory diseases, diabetes, and cancer are four of the most prevalent of these diseases. For the latter, the World Health Organization (WHO) reported that 8.8 million deaths are due to this cause, i.e., one in six deaths worldwide. Furthermore, the chemotherapeutic agents traditionally used for cancer treatment, unfortunately, have high toxicity, multi-resistance, and lack of selectivity, limiting their effectiveness. Therefore, the search for and development of new active compounds play a fundamental role in cancer control.

In this context, the arid macro-region of the Andes presents unique characteristics for the search for new bioactive compounds. This area extends from south-central Peru to northern Argentina and Chile, with an altitude ranging from 2,500 to 5,000 meters above sea level. Likewise, this region is characterized by low relative humidity, high solar radiation levels, 
región se caracteriza por una baja humedad relativa, altos niveles de radiación solar, falta de oxígeno y una gran oscilación térmica. Es en este hábitat donde crecen muchas especies vegetales que han desarrollado una gran variedad de compuestos bioactivos como adaptación al estrés ambiental, incluida la biosíntesis de metabolitos secundarios con actividades farmacológicas relevantes. La vegetación está dominada por una alternancia de pastos y arbustos estepas (tolares) que son utilizados por los habitantes del alto andino árido como fuente de alimento, medicina, forraje y construcción. Históricamente, las plantas medicinales han sido una fuente interesante de agentes terapéuticos.

En el caso particular de la ecorregión altoandina, podemos encontrar productos naturales con potencial terapéutico como la especie Senecio nutans (Asteraceae), que es ampliamente utilizada por las comunidades locales para el mal de montaña caracterizado por síntomas como dolores de cabeza, mareos, vómitos y fatiga. Los estudios iniciales han informado sobre la actividad citotóxica y antibacteriana del extracto etanólico obtenido de $S$. nutans. A la luz de la necesidad de nuevos fármacos contra bacterias multirresistentes y otras enfermedades, esta especie es candidata para nuevos estudios de modificación química y enfoques prácticos. También es de interés el género Parastrephia (Asteraceae), que presenta cinco especies: P. lucida, P. lephidophylla, $P$. phyllicaeformis, $P$. quadrangularis y $P$. teretiuscula, las cuales son utilizadas por las comunidades asentadas en la zona para aliviar el dolor de muelas, fracturas y contusiones, entre otras dolencias. Para muchas de estas especies se han reportado múltiples actividades biológicas encontradas en extractos alcohólicos y acuosos, como la antiinflamatoria, acaricida, antioxidante, antibacteriana y la antifúngica. Sin embargo, todavía no hay claridad sobre la identidad de los compuestos químicos responsables de la bioactividad. Recientemente se ha informado sobre la actividad citotóxica de la infusión de Bacharis alnifolia y su extracto etanólico.

Lo anterior correspondería al potencial terapéutico que tienen las especies vegetales de esta ecorregión, sin contar con el potencial alimentario. No obstante, muchas de las plantas medicinales son silvestres y en algunos casos se encuentran en peligro de extinción. Esto representa un desafío para la investigación agronómica de zonas áridas y en condiciones altoandinas, con el objeto de lack of oxygen, and a large thermal oscillation. In this habitat, many plant species thrive and have developed a wide variety of bioactive compounds as an adaptation to environmental stress, including the biosynthesis of secondary metabolites with relevant pharmacological activities. The vegetation is dominated by various grasses and steppe shrubs (tolares) used by the inhabitants of the arid high Andes as a source of food, medicine, forage, and construction. Historically, medicinal plants have been an extraordinary source of therapeutic agents.

In the particular case of the high Andean ecoregion, we can find natural products with therapeutic potentials, such as the species Senecio nutans (Asteraceae), which is widely used by local Andean communities for mountain sickness characterized by symptoms such as headaches, dizziness, vomiting, and fatigue. Initial studies have reported the cytotoxic and antibacterial activity of the ethanolic extract obtained from S. nutans. This species is a candidate for new chemical modification studies and practical approaches in light of the need for new drugs against multidrug-resistant bacteria and other diseases. Also of interest is the genus Parastrephias (Asteraceae), which has five species: P. lucida, P. lephidophylla, P. phyllicaeformis, P. quadrangularis, and $\mathrm{P}$. teretiuscula, which are used by the communities located in the area to relieve toothache, fractures, and bruises, among others. For many of these species, multiple biological activities have been reported in alcoholic and aqueous extracts, such as anti-inflammatory, acaricidal, antioxidant, antibacterial, as well as antifungal activity. However, there is still no clarity on the identity of the chemical compounds responsible for the bioactivity. Recently, the cytotoxic activity of Bacharis alnifolia infusion and its ethanolic extract has been reported.

Therefore would correspond to the therapeutic potential of the plant species in this ecoregion without considering the potential for food use. However, many of the medicinal plants are wild and, in some cases, are in danger of extinction. These characteristics present a challenge for agronomic research in arid zones and high Andean conditions in order to domesticate these species to increase the biomass and generate raw material to promote a new economic focus for the communities that are part of this desert zone. 
domesticar estas especies para aumentar la biomasa y generar materia prima a fin de promover un nuevo foco económico para las comunidades de esta área desértica.

A nivel local, un primer acercamiento lo estamos estableciendo en la Facultad de Ciencias Agronómicas de la Universidad de Tarapacá mediante el trabajo interdisciplinario, para la domesticación de la especie $S$. nutans a través de técnicas de cultivo de tejido in vitro, como alternativa de propagación vegetativa de plantas. Actualmente se trabaja para determinar la composición química y biológica de ejemplares domesticados y observar su correlación con la especie silvestre. De este modo, se espera obtener datos relevantes para el desarrollo de nueva información, tecnología y técnica, y su aplicación medicinal, entre otras.
At the local level, a first approach is being established at the Faculty of Agronomic Sciences of the Universidad de Tarapacá through interdisciplinary work for the domestication of the species S. nutans through in vitro tissue culture techniques as an alternative for vegetative propagation of plants. Currently, work is being done to determine the chemical and biological composition of domesticated specimens and see their correlation with the wild species. Thus, it is expected to gather relevant information for the development of new data, technology, and technique and their medicinal applications, among others. 